(1)

CrossMark

\title{
On Don Quixote and pink puffers: multi-organ loss of tissue COPD
}

\author{
Joan B. Soriano (10) ${ }^{1,2}$ and Pierre-Régis Burgel (103,4 \\ Affiliations: ${ }^{1}$ Instituto de Investigación, Hospital Universitario de la Princesa (IISP) Universidad Autónoma de \\ Madrid, Madrid, Spain. ${ }^{2}$ Sociedad Española de Neumología y Cirugía Torácica, Barcelona, Spain. ${ }^{3}$ University \\ Paris Descartes (EA2511), Paris, France. ${ }^{4}$ Dept of Respiratory Medicine, Cochin Hospital, AP-HP, Paris, \\ France.
}

Correspondence: Joan B. Soriano, IISP, Universidad Autónoma de Madrid, Diego de León 62, 28030-Madrid, Spain. E-mail: jbsoriano2agmail.com

@ERSpublications

More research to explore the newly proposed MOLT phenotype in COPD is welcome http://ow.ly/zkYR30hH4UP

Cite this article as: Soriano JB, Burgel P-R. On Don Quixote and pink puffers: multi-organ loss of tissue COPD. Eur Respir J 2018; 51: 1702560 [https://doi.org/10.1183/13993003.02560-2017].

\begin{abstract}
"Del poco dormir y del mucho leer, se le secó el cerebro, de manera que vino a perder el juicio" [1]; that is, "From little sleep and much reading, his brain dried up, so he came to lose his mind". It is unknown whether Don Miguel de Cervantes, or his most famous character, Don Quixote, ever tried tobacco, at that time newly traded from the New World. However, we invite you to revisit Frank Netter's wonderful "pink puffer" and "blue bloater" illustrations [2], iconic images of the classical chronic obstructive pulmonary disease (COPD) phenotypes of emphysema and chronic bronchitis. Do they have any resemblance to Alonso Quijano (Don Quixote) and his best friend Mr Sancho Panza, respectively (figure 1) [3]?

COPD keeps surprising us. In this issue of the European Respiratory Journal, CELLi et al. [4] report on a sophisticated analysis of the ECLIPSE cohort and propose a new COPD subgroup/phenotype, coined as "multi-organ loss of tissue" (MOLT). These MOLT patients would be those with emphysema progression and enhanced tissue loss in other body compartments, therefore undergoing excessive loss of pulmonary tissue (resulting in accelerated decline in forced expiratory volume in $1 \mathrm{~s}$ and higher emphysema scores by high-resolution computed tomography (CT)) that is also accompanied with loss of extrapulmonary tissue (lower body mass index (BMI), fat free mass index and functional capacity). It is hypothesised that these changes are related to abnormal tissue maintenance and associated with worse clinical outcomes (more exacerbations, hospitalisations and mortality). Interestingly, MOLT COPD patients had fewer diagnosed cardiovascular comorbidities and less systemic inflammation, with low serum interleukin-8, surfactant protein $\mathrm{D}$ and soluble receptor for advanced glycation end product, but higher serum club cell protein 16 . The metabolomics profile was also different in MOLT versus the rest of COPD patients.
\end{abstract}

Received: Dec 102017 | Accepted: Dec 112017

Conflict of interest: J.B. Soriano declares having received pharmaceutical company grants from GlaxoSmithKline (GSK) in 2011 and Chiesi in 2012 via CIMERA, his former home institution, and in 2014 and 2015 from Linde via Hospital Universitario de La Princesa; J.B. Soriano participated in speaking activities, advisory committees and consultancies during the period 2011-2017 sponsored by: Almirall, AstraZeneca, Boehringer-Ingelheim, CHEST, Chiesi, ERS, GEBRO, Grifols, GSK, Linde, Lipopharma, Mundipharma, Novartis, Pfizer, RiRL, Rovi, Sandoz, SEPAR and Takeda. J.B. Soriano has not received (directly or indirectly) funding from the tobacco industry or its affiliates. P-R. Burgel participated in speaking activities, advisory committees and consultancies during the period 2011-2017 sponsored by: Almirall, Aptalis, AstraZeneca, Boehringer Ingelheim, Chiesi, GSK, Novartis, Pfizer, Vertex and Zambon. P-R. Burgel has never received (directly or indirectly) funding from the tobacco industry or its affiliates.

Copyright CERS 2018 
FIGURE 1 Gustave Doré's drawings of Don Quixote (Alonso Quijano) and Sancho Panza. Reproduced from [3].

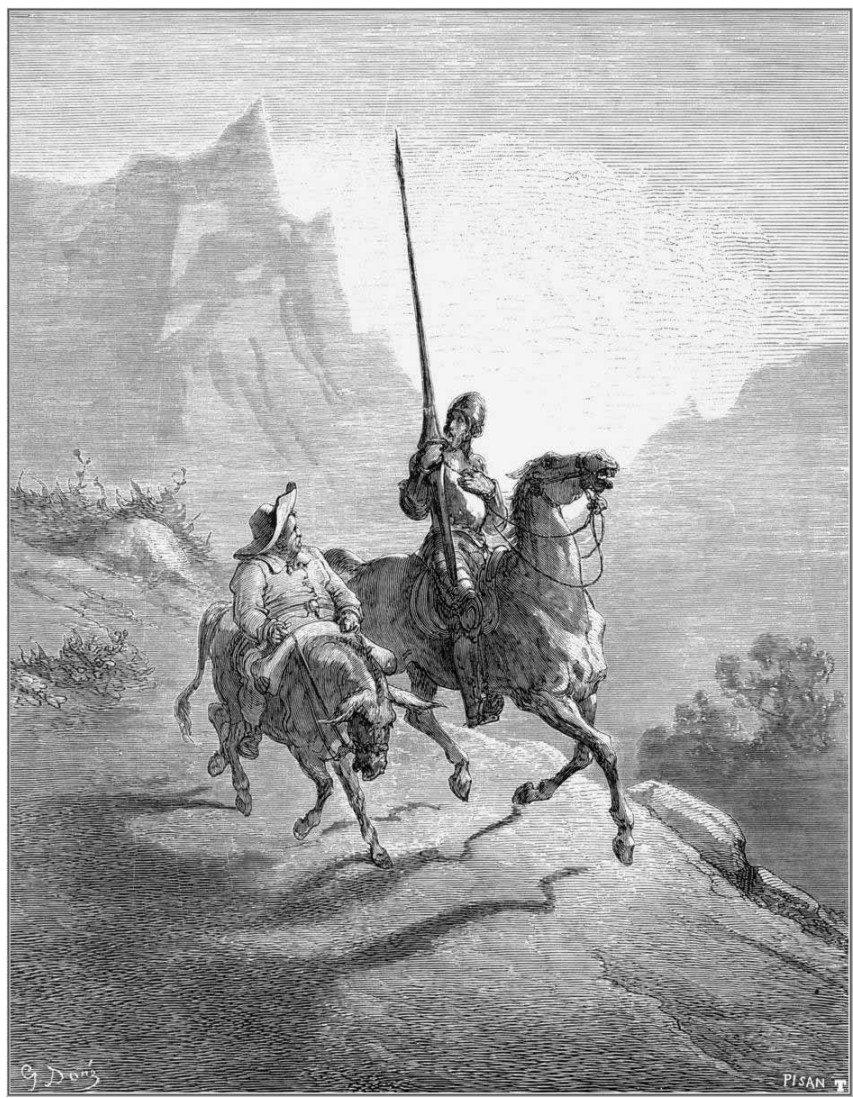

Results of the present study are consistent with previously identified phenotypes in patients with COPD. BURGEL et al. [5] reported that a clinical phenotype of subjects with COPD was composed of patients with severe airflow limitation, high rates of emphysema with extensive alveolar destruction on CT scans and hyperinflation, low BMI, osteoporosis, and low rates of cardiovascular comorbidities. In another study by the same group, investigating $>6000$ COPD patients, a simple algorithm was identified for the identification of clinical COPD phenotypes [6]. Consistent with the MOLT phenotype, patients with no cardiovascular comorbidity or diabetes also had severe airflow limitation, low BMI, high rates of exacerbations and high rates of mortality. The MOLT phenotype is also consistent with data from VANFLETEREN et al. [7], who studied clusters of systematically screened comorbidities in COPD patients, and reported that cachexia was often associated with emphysema and osteoporosis, but not with cardiovascular disease. It is further tempting to speculate that facial wrinkles, which have been associated with COPD and emphysema [8], are part of the same phenotype, related to loss of tissue (in this case elastin related). Very recently, FINGLETON et al. [9], in a neat, innovative study design with a dual replication of Chinese and New Zealand COPD phenotypes, also identified some MOLT-like characteristics within their Cluster A, which was also associated with more use of health services as per emergency visits and hospitalisations, although high-senstitivity C-reactive protein levels were high.

There are many strengths in this original ECLIPSE by-product, including the analysis of a large cohort of patients recruited in top centres from multiple countries, a comprehensive clinical characterisation, imaging data, in some cases biological data, and the longitudinal study design. They fulfil most (all) STROBE [10] and PROGRESS [11] requirements for observational and risk prediction research.

However, a number of limitations, some of them already listed by these authors, deserve discussion. First, the study is based on available data in the ECLIPSE study, from which some important information was missing. For example, CT scan data were restricted to emphysema, whereas no data on bronchial disease was reported. The loss of alveoli (and bronchioles) is often accompanied by thickening of the airway wall in the remaining bronchioles, which can be examined on a CT scan of the medium-sized airways [12]. Thus, it is likely that loss of tissue in alveoli (emphysema) could be associated with gain of tissue with airway wall thickening related to airway inflammation and fibrosis. Second, data on comorbidities in the ECLIPSE study were collected via questionnaires and it is conceivable that cardiovascular comorbidities were not fully identified in some patients, including those with the MOLT phenotype, as these 
comorbidities could be missed when not examined systematically [13]. Third, their results suggest that the MOLT phenotype could have a biological signature and thus could represent a separate COPD endotype associated with specific biological pathways. However, it should emphasised that this biological signature was based on data obtained in a relatively small subset of patients, and it therefore should be considered as hypothesis generating to date.

The clinical significance of MOLT is clear, as the enduringly pulmocentric view of COPD might be revisited with new evidence of damage in other organs and body systems beyond the lungs, as well as not only in the later stages of COPD but perhaps earlier in its natural history and even at onset of airflow limitation [14]. Hard COPD end-points like hospitalisations and even mortality were increased in these MOLT patients, so further avenues for researching the unmet need of these patients are encouraged. Independent replications in other sets of patients will be welcome. Speculatively, this MOLT COPD proposal, within the COPD phenotype research race, might be considered a new example of Planetary Health, connecting the very little with the very big, stirring established principles with newly collected translational evidence likely to benefit patients and ultimately the world itself [15].

There was no happy ending in Don Quixote. After many great adventures and many misfortunes too, Miguel de Cervantes let Don Quixote die, abandoning chivalry but completely recovering his lucid thinking, surrounded by his family and Sancho. But letting imagination fly, Don Quixote's body still bears resemblance to a cachectic, emphysematous, "imploding" pink puffer, perhaps with some resemblance to COPD patients with a MOLT phenotype. "Cosas veredes, amigo Sancho" or "You will see things, my friend Sancho".

\section{References}

1 de Cervantes M. El ingenioso hidalgo Don Quijote de la Mancha [The Ingenious Nobleman Sir Quixote of La Mancha]. Spain, Francisco de Robles, 1605.

2 The Netter Collection of Medical Illustrations. Respiratory System. www.netterimages.com/chapters.htm?book id=26\&id=15523\&page=148 Date last accessed: 23 November 2017.

3 Biblioteca virtual Miguel de Cervantes. Ilustraciones de El Quijote de Gustave Doré. Parte I Capítulo VII. www. cervantesvirtual.com/portales/miguel_de_cervantes/imagenes_quijote_dore/imagen/imagenes_quijote_dore_06_ cervantes_quijote_dore/ Date last accessed: November 23, 2017.

4 Celli BR, Locantore N, Tal-Singer R, et al. Emphysema and extrapulmonary tissue loss in COPD: a multi-organ loss of tissue phenotype. Eur Respir J 2018; 51: 1702146.

5 Burgel PR, Paillasseur JL, Peene B, et al. Two distinct chronic obstructive pulmonary disease (COPD) phenotypes are associated with high risk of mortality. PLoS One 2012; 7: e51048.

6 Burgel P-R, Paillasseur J-L, Janssens W, et al. A simple algorithm for the identification of clinical COPD phenotypes. Eur Respir J 2017; 50: 1701034.

7 Vanfleteren LE, Spruit MA, Groenen M, et al. Clusters of comorbidities based on validated objective measurements and systemic inflammation in patients with chronic obstructive pulmonary disease. Am J Respir Crit Care Med 2013; 187: 728-735.

8 Patel $\mathrm{BD}$, Loo WJ, Tasker $\mathrm{AD}$, et al. Smoking related COPD and facial wrinkling: is there a common susceptibility? Thorax 2006; 61: 568-571.

9 Fingleton J, Huang K, Weatherall M, et al. Phenotypes of symptomatic airways disease in China and New Zealand. Eur Respir J 2017; 50: 1700957.

10 von Elm E, Altman DG, Egger M, et al. The Strengthening the Reporting of Observational Studies in Epidemiology (STROBE) statement: guidelines for reporting observational studies. Lancet 2007; 370: 1453-1457.

11 Hemingway H, Croft P, Perel P, et al. Prognosis research strategy (PROGRESS) 1: a framework for researching clinical outcomes. BMJ 2013; 346: e5595.

12 McDonough JE, Yuan R, Suzuki M, et al. Small-airway obstruction and emphysema in chronic obstructive pulmonary disease. N Engl J Med 2011; 365: 1567-1575.

13 Rutten FH, Cramer MJ, Grobbee DE, et al. Unrecognized heart failure in elderly patients with stable chronic obstructive pulmonary disease. Eur Heart J 2005; 26: 1887-1894.

14 Bush A. Lung development and aging. Ann Am Thorac Soc 2016; 13: Suppl. 5, S438-S446.

15 Soriano JB, Soriano C, Fernández E. Respiratory Planetary Medicine. Arch Bronconeumol 2017; 53: $297-299$. 